\title{
UNCITRAL, security rights and the globalisation of the US Article 9 \\ GeRARD MCCORMACK*
}

Leeds University

\begin{abstract}
This article provides a critical analysis of the UN Commission on International Trade Law (UNCITRAL) proposals for developing - through its Legislative Guide (the Guide) - a "liberal" global secured credit law regime that opens up the range of assets that can be used for securing loans and that limits formal procedures required for taking security interests. The article argues that UNCITRAL's reliance on Article 9 of the US Uniform Commercial Code is problematic for various reasons. First, it neglects reference to indigenous secured credit law norms that also reflect national social policy choices in a range of countries. Second, it questions the idea that global "liberal" secured credit law of the kind articulated in the Guide helps to achieve "economic efficiency", since it relies on a narrow conception of private property. Moreover, by relying on existing property rights distributions, a liberal secured credit law can further entrench existing socio-economic disparities in a society. The article therefore casts doubt on the idea that UNCITRAL's Legislative Guide is an example of a successful "harmonized, modernized and marketized" secured credit law, and instead - in Polanyian terms - draws attention to its potential to further disembed markets in credit out of social relationships.
\end{abstract}

\section{Introduction}

U NCITRAL has recently produced a Legislative Guide on secured transactions, or secured credit law as it is variously called. ${ }^{1}$ The Guide follows the broad contours of Article 9 of the United States Uniform Commercial Code though it is not an exact copy. It aims to harmonise and modernise the law of secured credit across the globe. ${ }^{2}$ In

* The author would like to thank Terry Halliday, Peter Vincent-Jones and the anonymous referees for their helpful comments on earlier drafts. The usual disclaimer of course applies.

1 The Guide went through the UN General Assembly approval process in December 2008 - UN GA Res. 63/121 though the editorial revisions were only completed in 2009 and an intellectual property annex was "pre-released" on 15 July 2010. For the content of the Legislative Guide, see the UNCITRAL website www.uncitral.org/ - and for background see B Foex, L Thevenoz, S Bazinas (eds), Reforming Secured Transactions: The UNCITRAL Legislative Guide as an inspiration (Geneva: Schulthess 2007); H Buxbaum, "Unification of the law governing secured transactions: progress and prospects for reform" (2003) 8 Uniform Law Review 321.

2 UNCITRAL describes its mission as follows: "The core legal body of the United Nations system in the field of international trade law. A legal body with universal membership specializing in commercial law reform worldwide for over 40 years. UNCITRAL's business is the modernization and harmonization of rules on international business.": www.uncitral.org/ (last accessed 3 November 2011). This may represent mission creep from the UN resolution establishing UNCITRAL - Res. 2205(XXI) - which spoke of "progressive 
UNCITRAL's view, the Legislative Guide will aid the growth of individual businesses and also economic prosperity in general. Harmonisation and "modernisation" are assumed to equal "liberal" security regimes and the facilitation of secured credit. In this article, the modernisation-equals-liberalisation agenda is subjected to greater scrutiny and in doing so some key Polanyian themes are picked up, including the notion that markets have to be embedded in institutions to function effectively. ${ }^{3}$

UNCITRAL is not the only international organisation working on the design of an "efficient" legal regime for secured transactions. For example, the European Bank for Reconstruction and Development (EBRD) in $1994^{4}$ and the Organisation of American States (OAS) in $2002^{5}$ have both produced Model Laws and done follow-up work of greater or lesser intensity. The World Bank has formulated principles for Effective Insolvency and Creditors Rights Systems (revised in 2005) ${ }^{6}$ and has also produced a series of reports designed to evaluate the ease of doing business across the globe. As part of the evaluation process, the Doing Business reports have made use of a 10-point template measuring the degree to which secured credit and bankruptcy laws in particular jurisdictions "protect the rights of borrowers and lenders" and thus facilitate secured lending. ${ }^{7}$

So UNCITRAL is not alone in its efforts but UNCITRAL's work gains added credibility and legitimacy from its perceived representatives and its institutional aura as a United Nations organ. ${ }^{8}$ UNCITRAL was established as a UN offshoot in 1966 on the basis that a UN-related law reform body would provide more inclusive representation of the world's legal and economic systems and, accordingly, better coordination among other international actors. ${ }^{9}$ There has been considerable controversy recently over UNCITRAL's working methods and the extent to which its outputs reflect a "neoliberal" (American) agenda. ${ }^{10}$

[n. 2 cont.] harmonization and unification". The focus now on "modernization and harmonization" sees UNCITRAL in a more proactive light actively striving for the reform of global commercial law: see S Block-Lieb and T Halliday, "Harmonization and modernization in UNCITRAL's Legislative Guide on insolvency law" (2007) 42 Texas International Law Journal 475.

3 On Polanyian "embeddedness", see G Knippner et al., "Polanyi Symposium: a conversation on embeddedness" (2004) 2 Socio-Economic Review 109.

4 See its website at www.ebrd.com/pages/homepage.shtml and, for some of the later work done by its "secured transactions" team, see EBRD, Publicity of Security Rights: Guiding principles for the development of a charges registry (London: EBRD 2004) and Publicity of Security Rights: Setting standards (London: EBRD 2005), and see, generally, J-H Rover, Secured Lending in Eastern Europe: Comparative law of secured transactions and the EBRD Model Law (Oxford: OUP 2007).

5 See its website at www.oas.org/en/default.asp and, for later work, see OAS, Adoption of the Model Registry Regulations under the Model Inter-American Law on Secured Transactions, OEA/SerK/XXI.7 CIDIP-VII/RES.1/09 rev. 2, 16 October 2009. See also the work of the Asian Development Bank at www.adb.org which has produced a Guide to Movables Registries (2002).

6 See www.worldbank.org/ and the principles are also available as Annex 5 to World Bank Group, Secured Transactions Systems and Collateral Registries (Washington, DC: IFC 2010).

7 The template is available as Annex 3 to World Bank Group, Secured Transactions Systems, n. 6 above.

8 See T Halliday, "Legitimacy, technology and leverage: the building blocks of insolvency architecture in the decades past and decades ahead" (2007) 32 Brooklyn Journal of International Law 1081.

9 Schmitthoff Report (UN Doc. A/6396), reprinted in (1966) 1 UNCITRAL Yearbook 2 and available online at www.uncitral.org/ and associated links.

10 For a discussion of UNCITRAL working methods referring to earlier controversies, see "UNCITRAL rules of procedure and methods of work: note by the Secretariat" A/CN9/676 (2009) and A/CN9/697 (2010). Note too UN General Assembly Official Records 65th session, Supplement No 17 (A/65/17) Annex 111. The controversies covered the role and status of non-state actors, primarily US-based organisations, in UNCITRAL deliberations. On the dangers of "interest group capture", see R Cranston, "Theorizing transnational commercial law" (2007) 42 Texas International Law Journal 597, at fnn. 49-55. For analogies with the American Article 9 drafting process, see A Schwartz and R Scott, "The political economy of private 
This article does not engage directly with this controversy but it does consider the closeness in approach between the UNCITRAL Secured Transactions Guide and the American Article 9 and the extent to which this proximity may inhibit the prospects of the UNCITRAL Guide achieving widespread international acceptance. A key argument in the article is that the avowed aim of the Guide to reform the law worldwide along neoliberal American lines is fraught with difficulty not least by overlooking the regulatory and cultural plurality of the countries on which it seeks to have an impact.

The article brings out some of the themes that emerge from Karl Polanyi's The Great Transformation and were highlighted by Joseph Stiglitz in his foreword to the 2001 edition. ${ }^{11}$ These include the myth of completely self-correcting markets; the "embeddedness" of markets in institutions; the interplay between voluntariness and coercion in the functioning of markets; the importance of historical and cultural context and sensitivities; and, finally, the distributional consequences of deference to market-based decision-making.

The article begins by asking: what is the effect of recognising security rights? In short, what do security rights do for you? In a Polanyian perspective, security rights could be considered as "embedding" the market by reducing the possibility of market failure and avoiding the attendant consequences of default. But, on another view, security rights seek to ensure the effective functioning of markets and thus further entrench the self-regulation paradigm. The second part of the article asks why the law of secured credit should be harmonised, particularly in the "liberal" American-nuanced way that the UNCITRAL Guide seeks to do? The third part considers why "liberal" secured credit regimes are considered to be beneficial. The fourth part addresses in greater detail critical perspectives on the international harmonisation and modernisation agenda. The final part concludes and summarises the discussion counselling against the "silver bullet" of secured transactions reform, especially in the American-oriented manner that the Guide seeks to effect.

\section{Security rights}

While there is probably no universally recognised definition of security rights, it is generally taken as meaning a right over property to ensure the payment of money or the performance of some other obligation. The property over which security is taken is referred to as "secured" or "collateralised". The security taker has a superior claim to payment of the debt out of the secured property than the generality of the debtor's creditors and will generally have access to speedier enforcement mechanisms. In the event that the secured debt is not repaid, the security taker will normally have a right of sale over the secured assets, whether unilaterally or by seeking the intervention of an administrative mechanism or court. The secured creditor has therefore greater leverage than unsecured creditors. The debtor may also be more likely to pay a secured debt - failure to pay can result in the loss of a crucial asset for the debtor's business - thereby giving the secured creditor a stronger hand in debtrestructuring negotiations. Security also opens up the possibility of the creditor availing of self-help remedies, although self-help is a controversial concept in many jurisdictions, not least because it is seen to be possibly inconsistent with constitutional guarantees safeguarding peaceful possession of property

[n. 10 cont.] legislatures" (1995) 143 University of Pennsylvania Law Review 595; E Janger "Predicting when the uniform law process will fail: Article 9, capture, and the race to the bottom" (1998) 83 Iowa Law Review 569. More generally, see G McCormack, Secured Credit and the Harmonisation of Law (Cheltenham: Edward Elgar 2011).

11 K Polanyi, The Great Transformation (Boston: Beacon Press 2001). 
Economists suggest that security addresses the problems of adverse selection, moral hazard and uninsurable risk in lending decisions. ${ }^{12}$ Security aligns the incentives of creditors and borrowers and adds a credible commitment to the relationship. Security performs a disciplinary function and is a cornerstone of the theory of control rights and incomplete contracts that has been developed by Oliver Hart and others. ${ }^{13}$

Adverse selection refers to the fact that some borrowers may turn out to be unreliable or untrustworthy. A lender cannot simply raise interest rates to screen out these borrowers because honest borrowers with sound projects will drop out of the picture as well. The potential pay-off from the project may not be enough to meet the borrowing costs. Where security is taken, however, adverse selection problems are addressed more powerfully. The lender can back up its assessment of the character of the borrower and the soundness of the business plan with information on the value of the collateral. As well as the revenues generated from the project, the lender can look to the collateral for repayment. Moral hazard refers to the possibility that a borrower may abscond with the loan. The larger the loan, the greater the moral hazard but, if the borrower provides security, the lower are the lender's costs in monitoring moral hazard. The borrower has given the lender a hostage against flight risk in the shape of security. The insurance risk arises from the fact that the borrower may not be able to repay due to certain events that are not easily insurable, or insurable at all. Uninsurable risk may be reduced in unsecured lending through making smallish loans to a large number of borrowers, i.e. spreading. Security allows more concentrated lending and also reduces uninsurable risk since the security serves as an alternative repayment mechanism. ${ }^{14}$

By way of summary, security rights provide the creditor with property rights which strengthen the creditor's contractual claims against the debtor in various ways. Firstly, the security taker should have priority over other creditors in the event of the debtor becoming insolvent. Secondly, the security-taker should have a measure of control over the secured assets or at least share control with the debtor, thereby strengthening the debtor's hands in restructuring negotiations. Thirdly, the security-taker should have easier enforcement mechanisms available to it than the generality of creditors, including a power of sale over the secured assets. Fourthly, the easier debt enforcement opportunities may include selfhelp measures such as sale of the secured assets through unilateral action by the creditor, without having to seek the permission of a court or administrative agency. But not all these features are present in every jurisdiction.

Not all jurisdictions, for instance, recognise the full priority of secured claims. A proportion of secured asset realisations may be carved out, or set aside, for the benefit of unsecured creditors. There may also be restrictions on the enforcement of security rights and, in particular, limitations or, indeed, wholesale prohibition, on self-help enforcement. The overall effect, however, of recognising security rights is to improve a creditor's hand in dealing with adverse selection, moral hazard and uninsurable risk issues.

12 See, generally, J Stiglitz and A Weiss, "Credit rationing in markets with imperfect information" (1981) 71 American Economic Review 393. See also G Akerlof "The market for 'lemons': qualitative uncertainty and the market mechanism” (1970) 84 Quarterly Journal of Economics 488.

13 See, generally, O Hart and J Moore "Default and renegotiation: a dynamic model of debt" (1998) 113 Quarterly Journal of Economics 1.

14 See H Fleisig, "The economics of collateral and collateral reform" in F Dahan and J Simpson (eds), Secured Transactions Reform and Access to Credit (Cheltenham, Edward Elgar 2008), p. 81. 


\section{Why harmonise the law of secured credit?}

In short, UNCITRAL has advocated harmonisation of the law of secured credit to make the law more liberal and facilitative of security and this, in turn, is seen as producing more economic growth. UNCITRAL has suggested the removal of restrictions on the taking of security and increasing the range of assets that can be used as security. It has also suggested the introduction of mechanisms for the registration of security rights thereby enhancing the available information about such rights. In the UNCITRAL view: ${ }^{15}$

The key to the effectiveness of secured credit is that it allows borrowers to use the value inherent in their assets as a means of reducing credit risk for the creditor. Risk is mitigated because loans secured by the property of a borrower give lenders recourse to the property in the event of non-payment. Studies have shown that as the risk of non-payment is reduced, the availability of credit increases and the cost of credit falls. Studies have also shown that in States where lenders perceive the risks associated with transactions to be high, the cost of credit increases as lenders require increased compensation to evaluate and assume the increased risk.

There is a suggestion that too many countries have too many restrictions on the taking of security and that countries with "inadequate" secured transactions regimes have suffered significant losses in gross domestic product (GDP) in consequence. These studies suggest that gaps or weaknesses in collateral-based credit systems hinder financial and economic development. ${ }^{16}$ Simply stated, banks and other financial institutions will not engage in largescale lending activities if their position as secured creditors in the liquidation of their borrowers is not sufficiently certain, or that sufficient means for the enforcement of security are not available. More controversially, it has also been suggested that businesses in less developed financial systems and civil law countries substitute less efficient forms of external finance, trade credit and other sources of funds for bank loans and equity. ${ }^{17}$

There are also sector-specific studies that purport to demonstrate the value of particular types of collateral and the economic impact of a stable legal environment for security creation and enforcement. One such study concerns the 2001 Cape Town Convention on International Interests in Mobile Equipment and the Protocol on Matters Specific to Aircraft Equipment. ${ }^{18}$ It was estimated that savings to the aircraft industry from the creation of a sound international legal framework governing aircraft financing amounted to \$4bn a year in borrowing costs. Moreover, since 2003 the Export-Import Bank of the United States "has offered a one-third reduction of its exposure fee on . . . financings of

15 "Draft legislative guide on secured transactions: report of the Secretary General", A/CN 9/WG VI/WP 2 (2002) Addendum 1 at para. 4 and see also the report from the World Bank Group, Secured Transactions Systems, n. 6 above, pp. 6-13.

16 See, generally, H Fleisig, "Economic functions of security in a market economy" in J Norton and M Andenas (eds), Emerging Financial Markets and Secured Transactions (London: Kluwer 1998), p. 15. See also D Arner, C Booth, P Lejot and B Hsu, "Property rights, collateral, creditor rights and insolvency in East Asia" (2007) 42 Texas International Law Journal 515.

17 See the series of studies carried out by the so-called "law matters" or "legal origins" thesis: R La Porta, F Lopez de Silanes, A Shleifer and R Vishny. Their work includes "Legal determinants of external finance" (1997) 52 Journal of Finance 1131 and "Law and finance" (1998) 106 Journal of Political Economy 1113.

18 The Cape Town Treaty consists of a main convention that sets out the general governing rules, and a series of supplemental protocols that set out specific rules for particular types of collateral (e.g. aircraft). See, generally, R Goode "Transcending the boundaries of earth and space: the Preliminary Draft UNIDROIT Convention on International Interests in Mobile Equipment" (1998) 3 Uniform Law Review 52; I Davies, "The new lex mercatoria: International Interests in Mobile Equipment” (2003) 52 ICLQ 151. 
new US-manufactured large commercial aircraft for buyers in countries that ratify . . and implement the Cape Town [Convention]". ${ }^{19}$

There is a consensus among international financial institutions that a "liberal" secured credit regime is a general social and economic good. Two examples serve to highlight that consensus. The first example comes from the late-1990s upheavals in the "tiger" economies of East Asia. In the aftermath, an influential G22 report highlighted the importance of debtor/creditor regimes and also set out the features that, in its view, should be contained in such regimes: ${ }^{20}$

The law should permit . . . all economically important assets to serve as collateral for a loan: and security interests in tangible property . . . and in intangible property ... to be created. All economically important agents should be able to act as lenders and as borrowers in secured transactions and all economically important secured transactions should be permitted. The creation of security interests should be inexpensive relative to the amounts lent.

Secondly, when the former socialist economies in Central and Eastern Europe were undergoing the transition to a more free-market-oriented system, the task of reforming credit laws assumed a high priority on the legislative agenda. ${ }^{21}$ Organisations like the EBRD considered that such laws impacted in a crucial way on the pace of private sector investment activity and were essential in fostering market-based decision-making. ${ }^{22}$ Consequently, EBRD produced a Model Law on Secured Transactions to guide states in their reform efforts. ${ }^{23}$

But the UNCITRAL Guide goes much further than the EBRD Model Law. In the context of secured credit law, it is typical to draw a distinction between common law and civil law jurisdictions. ${ }^{24}$ Common law jurisdictions - generally sympathetic to the concepts of party autonomy and self-help - have a liberal attitude towards security, allowing security interests to be taken with a minimum of formality over both present and future assets to secure existing and future indebtedness. "[T] hey allow universal security rather than require specific security." 25 By contrast, civil law jurisdictions have been more cautious in their approach to non-possessory security and typically have imposed restrictions on the taking of security.

The EBRD Model Law attempts to accommodate features from both civil law and common law traditions whereas the UNCITRAL guide is firmly in the common law mould.

19 News Release, "Cape Town Treaty on Cross-Border Financing of Aircraft, Helicopters and Aircraft Engines takes effect today (March 1)", 28 February 2006, www.exim.gov/pressrelease/ (last accessed 3 November 2011); and see, generally, R Goode, H Kronke, and E McKendrick, Transnational Commercial Law (Oxford: OUP 2007), p. 441: "the international regime established by the Convention could reduce borrowing costs by several US \$billion a year".

20 Report of the Working Group on International Financial Crises (Washington, DC: IMF 1988), p. 47, available on the IMF website www.imf.org/external/index.htm.

21 See, generally, Rover, Secured Lending, n. 4 above.

22 See also D Berkowitz, K Pistor and J-F Richard, "The transplant effect” (2003) 51 AJCL 163, p. 164: "newly designed model laws for secured transactions marketed the value of Western law to their counterparts in the East, backing their campaign to transplant their home legal system with financial aid promises and/or the prospect of joining the European Union."

23 EBRD, Model Law on Secured Transactions (London: EBRD 1994); on which see Rover, Secured Lending, n. 4 above.

24 See S van Erp, "Civil and common property law: caveat comparator - the value of legal historical-comparative analysis" (2003) 11 European Review of Private Law 394, and, more generally, R Cuming, "The internationalization of secured financing law: the spreading influence of the concepts of UCC, Article 9 and its progeny" in R Cranston (ed.), Making Commercial Law: Essays in honour of Roy Goode (Oxford: Clarendon Press 1997), p. 499.

25 R Goode, "Security in cross border transactions" (1998) 33 Texas Journal of International Law 47, p. 48. 
Moreover, it goes far beyond the English common law appropriating the main features of Article 9 of the American Uniform Commercial Code. For instance, the UNCITRAL guide rejects the idea of carving out a proportion of collateral realisations for the benefit of unsecured creditors - an idea that finds recognition in the UK Insolvency Act, ${ }^{26}$ but was dismissed in the US. ${ }^{27}$ Likewise, the UNCITRAL guide adopts a functional approach towards the creation and registration of security rights effectively recharacterising certain transactions as security rights although they were not ostensibly designed as such. Again, this conforms with the approach evidenced in the US Article 9 but is one that is at variance with the English common law. In addition, in the details of the filing system suggested for security interests, the UNCITRAL Guide maps onto the American rather than the English system.

Filing systems are designed to address information asymmetries in credit markets. ${ }^{28}$ Lenders depend on information about borrowers to perform an initial screening function as well as monitoring and controlling the actions of borrowers during the lifetime of the loan. Information-sharing facilities may allow lenders to allocate credit more efficiently and to increase overall lending volumes. Such facilities may also improve the behaviour of borrowers since there is less of an opportunity, or incentive, to over-borrow from several banks simultaneously without any of them knowing. The UNCITRAL Guide, however, follows the Article 9 notice-filing system under which the security agreement itself is not filed but instead a so-called "financing statement" providing limited information. Notice filing is party specific rather than transaction specific. The information filed is an invitation to further inquiry rather than a synopsis of the transaction. The filed notice merely indicates that a person may have a security interest in the collateral concerned but further inquiry by a searcher from the potential creditor and/or debtor will be necessary to ascertain the facts. A degree of scepticism about the merits of notice filing seems appropriate. ${ }^{29}$ Divorcing registration from particular individual transactions opens up the possibility that the register may become less reliable as a source of information since a searcher cannot be sure whether a particular entry relates to an actual transaction or to a transaction that was contemplated but never in fact materialised. ${ }^{30}$

\section{Why "liberal" security regimes are considered to be beneficial}

In short, liberal security regimes are considered to be beneficial because they are seen to promote economic growth. This is for two general reasons. Firstly, there is the contract/property rights argument which goes along the lines that the secured creditor has bargained for rights of a proprietary nature. The law should respect this contractual bargain and the property rights acquired by the secured creditor in the debtor's assets. Recognition of property rights is good, so the argument goes, for economic growth. Secondly, security is a risk-reduction device and therefore increases the availability and lowers the cost of

26 S. $176 \mathrm{~A}$ and see also Insolvency Act 1986 (Prescribed Part) Order 2003.

27 S L Harris and C W Mooney, "Measuring the social costs and benefits and identifying the victims of subordinating security interests in bankruptcy" (1997) 82 Cornell Law Review 1349.

28 See F Lopez de Silanes, “Turning the key to credit: credit access and credit institutions" in Dahan and Simpson (eds.), Secured Transactions Reform, n. 14 above, p. 6.

29 J White, "Reforming Article 9 priorities in light of old ignorance and new filing rules" (1995) 79 Minnesota Law Review 529, p. 530; U Drobnig, "Present and future of real and personal security" (2003) European Review of Private Law 623, p. 660. According to the Scottish Law Commission, the only civil law jurisdictions to have introduced notice filing are Quebec and Louisiana; see discussion paper, Registration of Rights in Security by Companies (Edinburgh: Scottish Law Commission October 2002), para. 1.28.

30 For a far fuller discussion of the technical and other merits of the UNCITRAL Secured Transactions Guide versus other secured transactions model laws and instruments, see G McCormack, "American private law writ large?: The UNCITRAL Secured Transactions Guide" (2011) 60 ICLQ 597. 
credit. The effect of minimising risk is to encourage lenders to make loans that they would not otherwise make and also to reduce the risk premium that a lender might otherwise input into the interest rate calculations. The overall effect is to facilitate economic activity.

The general value of property rights argument is supported by the new institutional economics school, led by Douglass North, whose proponents argue that financial systems require certain legal and institutional elements to be in place to function effectively. ${ }^{31}$ These include the recognition of property rights and the use of property to secure loans. This "property rights including security rights will produce economic growth" argument has been reinforced by the "legal origins" or "law matters" thesis advanced by La Porta, Lopez de Silanes, Shleifer and Vishny. ${ }^{32}$ It is also supported by an indirect offspring of La Porta the Doing Business reports commissioned by the World Bank. ${ }^{33}$ The thesis was first developed in the area of investor protection but it also encompasses creditor rights and legal institutions more generally. The thesis says that "law matters" in that legal institutions impact on economic growth. ${ }^{34}$ But more controversially, the thesis also asserts that countries that adopted the common law perform better than those with a civil law origin. Legal families are evaluated on the basis of their economic performance and, generally, the common law comes out as superior.

The alleged superiority of the common law is founded on two propositions. The first is that judges have greater independence in common law than in civil law systems, so that the government has less influence on market developments. The second is that the common law, being based on caselaw rather than on legislative codes, is more responsive to the changing conditions and requirements of society.

The legal origins literature has, however, been criticised for a US-centric approach. ${ }^{35}$ The thesis suggests that US law is the benchmark, the goal of legal convergence, the end of (legal) history. The thesis has also been criticised as the work of a small group of economists whose knowledge of legal differences and cross-cultural legal comparisons displays deficiencies. ${ }^{36}$ The civil/common law distinction is fundamental to the thesis with membership of a legal family seen as a cause for past and present economic development. But the way in which legal systems are assigned by proponents of the thesis to one or other legal family is crude. For example, France is assigned to the same legal family as Lithuania but their economies (and their laws) are like apples and oranges in many other ways. All legal systems are mixed to a degree and the civil law/common law divide seems especially irrelevant for the sphere of economic law covered by the legal origins literature. Other

31 North's theories are developed in Institutions, Institutional Change and Economic Development (New York: CUP 1990). See also C Goodhart, "Economics and the law: too much one-way traffic?" (1997) 60 MLR 1, p. 5 (referring to Mancur Olson).

32 See La Porta et al., "Legal determinants", and "Law and finance", n. 17 above. R La Porta, F Lopez de Silanes and A Shleifer refine the "legal origins" thesis and defend it against criticisms in "The economic consequences of legal origins" (2008) 46 Journal of Economic Literature 285.

33 The Doing Business reports are available at www.doingbusiness.org/.

34 But see M Roe, "Legal origin and modern stock markets" (2006) 120 Harvard Law Review 460 who argues that politics is a more relevant causal factor. In "The economic consequences", n. 32 above, La Porta et al. use "legal origins" as a sort of proxy for politics. They "adopt a broad conception of legal origin as a style of social control of economic life (and maybe of other aspects of life as well) ... [They] argue that common law stands for the strategy of social control that seeks to support private market outcomes, whereas civil law seeks to replace such outcomes with state-desired allocations."

35 See, generally, R Michaels, "Comparative law by numbers? Legal origins thesis, doing business reports and the silence of traditional comparative law" (2009) 57 AJCL 765 and the literature referred to therein. There is also a symposium on the legal origins thesis in the 2009 Brigham Young University Law Review.

36 See U Braendle, "Shareholder protection in the USA and Germany: 'law and finance' revisited" (2006) 7 German Law Journal 257. 
aspects of a society, such as politics, culture or religion, and geographical position are much more likely to influence economic development than membership of a particular legal family. 37

Despite the criticism, the legal origins literature has heavily influenced the Doing Business reports issued by the International Finance Corporation (IFC), a member of the World Bank Group. These reports purport to measure and compare the "ease of doing business" in more than 130 countries worldwide. ${ }^{38}$ Indeed, the lead author of the earlier Doing Business reports is a frequent co-author with the originators of the legal origins thesis. ${ }^{39}$ While the reports purport to assess attractiveness for investors rather than economic performance per se, there are obvious linkages between the two. The reports have tended to show that credit bureaus, stronger creditor rights and simpler civil procedure rules have a significant impact on access to credit. ${ }^{40} \mathrm{It}$ is argued that strong creditor protection should lead to deeper credit markets and better financing for firms and individuals. The Doing Business reports have identified many laws, rules and institutions, in four basic categories, that constitute the basis for private credit: (1) mechanisms for the registration of property; (2) information sharing arrangements or credit bureaus; (3) collateral rules and creditor rights; and (4) contract enforcement. The reports conclude that the wealth of a particular country is an important indicator of the effectiveness of institutions in that country that guarantee access to credit. ${ }^{41}$ In the main, richer countries are said to have more expeditious procedures to register ownership of property; a higher presence of private credit bureaus; greater coverage and quality in terms of the information collected by information-sharing institutions; more extensive creditor rights and security rights, as well as better measures of contract enforcement.

The Doing Business reports have major resonance with national governments which have often taken conscious steps to improve a country's rankings. This may not be a positive move, however, not least because countries may be more inclined to improve their rankings by "gaming" the system rather than taking the politically more problematic step of addressing problems highlighted in the reports. ${ }^{42}$ Otherwise the Doing Business reports may be subjected to similar criticism as the legal origins thesis; namely, faulty research, insufficient attention to detail, a common law bias (actual or perceived) and a preference for free-market solutions and deregulation over other values, such as solidarity and justice and the preservation of separate legal cultures. ${ }^{43}$

The deregulatory and free-market agenda was quite explicit in the first Doing Business report in 2004 which purported to show that a "heavy" regulatory regime produced the

37 See M Siems, "Legal origins: reconciling law and finance and comparative law" (2007) 52 McGill Law Journal 55. See also on legal origins P Wood, Law and Practice of International Finance (London: Sweet \& Maxwell 2008), ch. 3 .

38 See www.doingbusiness.org/ (last accessed 1 November 2011).

39 The reference is to Simeon Djankov, now Finance Minister and Deputy Prime Minister of Bulgaria and for co-authored publications see S Djankov, R La Porta, F Lopez de Silanes and A Shleifer, "The regulation of entry" (2002) 117 Quarterly Journal of Economics 1; "Courts" (2003) 118 Quarterly Journal of Economics 453 and also with J Botero, “The regulation of labor” (2004) 119 Quarterly Journal of Economics 1339.

40 See F Lopez de Silanes, "Turning the key to credit" in Dahan and Simpson (eds), Secured Transactions Reform, n. 14 above.

41 Lopez de Silanes, "Turning the key to credit" in Dahan and Simpson (eds), Secured Transactions Reform, n. 14 above. p. 20.

42 R Michaels, "Comparative law by numbers? Legal origins thesis, doing business reports and the silence of traditional comparative law" (2009) 57 AJCL 765, p. 772; B Arrunada, "Pitfalls to avoid when measuring institutions: is doing business damaging business?” (2007) 35 Journal of Comparative Economics 729.

43 See, generally, G Sarfaty, "Why culture matters in international institutions: the marginality of human rights at the World Bank" (2009)103 American Journal of International Law 647. 
worst results in terms of economic outcomes because it was usually associated with inefficiency within public institutions, long delays in reaching decisions, high costs of administrative formalities, lengthy judicial proceedings, higher unemployment and more corruption, less productivity, and lower investment. ${ }^{44}$ The report also said "Common law countries regulate the least. Countries in the French civil law tradition the most. However, heritage is not destiny." The overall conclusion was a stark one that "one size can fit all" in respect of the legal regulation of business.

There have, however, been criticisms of the Doing Business reports from the Independent Evaluation Group within the World Bank. In a 2008 critique, the Independent Evaluation Group recommended greater transparency and some modifications to the Doing Business methodology. ${ }^{45}$ The critique also suggests that the focus on regulatory costs and burdens should only be one dimension of any overall reform of the investment climate in a particular country. Essentially, the Doing Business reports use a creditor-centred approach with the highest grading given to countries that emphasise private contractual solutions rather than court-based ones. This approach appears one-dimensional and overly simplistic. It also ignores the recent economic success of countries such as China where many of the desiderata considered necessary by international financial institutions, such as strong property rights, are absent. ${ }^{46}$

In recent times, a popular exponent of the linkage between property rights and economic development has been Hernando De Soto in writings such as The Mystery of Capital: Why capitalism triumphs in the west and fails everywhere else. ${ }^{47}$ De Soto argues that people in developing countries lack an integrated formal property system and he contrasts this with the US where, in his view, a clear system of property rights was created from early on. De Soto suggests that the absence of such a system makes it impossible for the poor to leverage informal ownership into collateral for the extension of credit. In De Soto's view, the combined effect of bureaucracy and outdated legal systems is to drive economic activities underground in developing countries and to stifle investment activity. But property systems in the wealthy West allow assets, through ownership documentation, to lead an "invisible, parallel life alongside their material existence". ${ }^{48}$ In developing countries, comparable means of documentation are lacking thereby creating "dead capital".

Formal property systems are said to produce six effects that facilitate the generation of capital. The first is fixing the economic potential of assets. De Soto uses the analogy of generating electric power from a lake in the mountains, suggesting that the potential value locked up in an asset can be revealed, transformed and energised in the same way. ${ }^{49}$ The second effect is the integration of dispersed information into one system. The third is making people accountable - incorporation into a more integrated legal system facilitates

44 See the 2004 Doing Business report, p. 83: "Heavier regulation of business activities generally brings bad outcomes, while clearly defined and well-protected property rights enhance prosperity".

45 World Bank Independent Evaluation Group, Doing Business: An independant evaluation - Taking the measure of the World Bank-IFC Doing Business indicators (Washington, DC: World Bank 2008).

46 C Paulus, "Global insolvency law and the role of multinational institutions" (2007) 32 Brooklyn International Law Journal 755, p. 762. For somewhat varying views on the Chinese example, see World Bank Group, Secured Transactions Systems, n. 6 above, pp.67, 104.

47 H De Soto, The Mystery of Capital (London: Black Swan 2008). See also G Hardin, "The tragedy of the commons" (1968) 162 Science 1243, but for refinement and criticism of Hardin's work see Governing the Commons: The evolution of institutions for collective action (New York: CUP 1990) by the winner of the 2009 Nobel Prize for Economics Elinor Ostrom. For a much more nuanced analysis, see R Ellickson, "Property in land" (1992) 102 Yale Law Journal 1315 and, in particular, the conclusion at p. 1397.

48 De Soto, The Mystery of Capital, n. 47 above, p. 7.

49 Ibid. pp. 47-61. 
individual accountability. The fourth effect is to put assets into a more accessible condition so that they can do additional work. Assets become "fungible" and can be fashioned to suit practically any transaction. Fifthly, increased fungibility in turn helps to network people and convert citizens into individually identifiable and accountable business agents. Increased information and integrated law makes risk more manageable not least by facilitating the pooling of assets to secure debts. The final effect is the protection of transactions. To sum up, a documented system of ownership can:

provide a link to the owner's credit history, an accountable address for the collection of debts and taxes, the basis for creation of reliable public utilities, and a foundation for the creation of securities (like mortgage backed bonds) that can be rediscounted and sold in secondary markets. ${ }^{50}$

De Soto's work has been lavishly praised, with Bill Clinton, for example, calling him the "world's greatest living economist", 51 but the work has also attracted criticism on a number of grounds. Some have questioned the statistical validity of the claims about the size of the informal economy. ${ }^{52}$ Others would argue that it is excessively narrow in its approach to economic development - basically a "single bullet" approach. It is suggested that there should be a greater emphasis on culture and the local social context, and how local conditions affect people's perceptions of their opportunities. ${ }^{53}$ There are further empirical studies that take issue with the link between property registration mechanisms and the increase in credit to the poor. ${ }^{54}$ Also many micro-businesses operate in the informal sector beneath the radar screen of the authorities. ${ }^{55}$ They may not see the merit in availing of a reformed law if this meant appearing on the official radar. Moreover, they may not possess much in the way of conventional collateral, and reforming collateral law is unlikely to change that situation. In many countries, improved access to credit has only come about through the willingness of alternative financial institutions to look at cash flows rather than assets. Highlighting secured lending and collateral may put "undue attention on an issue that the pioneer microfinance organizations and practitioners have worked very hard to reduce to a lower status". 56

There is also the experience in De Soto's native Peru which suggests that property registration, of itself, is unlikely to have much effect. To bring about concrete reform, it may have to be followed by more politically challenging steps, such as improving the norms and efficiency of the judicial system, as well as rewriting bankruptcy codes and restructuring financial market regulation. Reforms of this nature may entail much more challenging

50 De Soto, The Mystery of Capital, , n. 47 above, p. 7.

51 See the University of North Carolina at Chapel Hill, News Release, 19 October 2004, available at www.unc.edu/news/archives/oct04/fpg_desoto101904.html and see the praise for De Soto on the Cato Institute website from Richard Nixon and Ronald Reagan www.cato.org/special/friedman/ desoto/praise.html (last accessed 3 November 2010).

52 See the review of De Soto's other famous book El Otro Sendero (The Other Path) by R Rossini and J Thomas (1990) 18 World Development 125.

53 See R Samuelson, “The spirit of capitalism” (2001) 80(January/February) Foreign Affairs 205: "Unfortunately, de Soto strains too much. He wants to make property rights - or their absence - the center of everything."

54 See S Galliani and E Schargrodsky, Property Rights for the Poor: Effects of land titling, Ronald Coase Institute Working Paper (January 2009), who conclude: "Our results suggest that land titling can be an important tool for poverty reduction, albeit not through the shortcut of credit access, but through the slow channel of increased physical and human capital investment, which should help to reduce poverty in the future generations."

55 M Holtmann, "Use of security in challenging environments: the microfinance perspective" in Dahan and Simpson (eds), Secured Transactions Reform, n. 14 above, p. 159.

56 Ibid. p. 167. 
choices for policymakers. ${ }^{57}$ Radical critiques suggest that one must look more to the current distribution of property rights rather than the formalisation of such rights. Mattei, for instance, argues that the "formalisation" movement uses an illusory economic theory to justify the freezing and naturalisation of the status quo. ${ }^{58}$

Whatever the validity of the ideological criticism, certainly De Soto's rhetoric is overblown. "Trifling details", such as significant differences between legal systems and property registration systems in developed countries, simply do not concern him. According to De Soto, 59 in the West "all the property records (titles, deeds, securities and contracts that describe the economically significant aspects of assets) are continually tracked and protected as they travel through time and space". Regimes of personal property without registration thrive, however, in many parts of the developed world. It is almost as if De Soto is carried away by his own rhetoric and forgets the need for qualification, asserting that "citizens in advanced nations can obtain descriptions of the economic and social qualities of any available asset without having to see the asset itself". ${ }^{60}$ As a bald, general statement this is simply not true and casts doubt on the accuracy of De Soto's own research and his overall thesis about the role of registration of assets as a necessary concomitant of economic development. ${ }^{61}$

De Soto also ignores the fact that Latin American countries, including Peru, have civil codes modelled on the Napoleonic codes of France and Spain. ${ }^{62}$ These codes may not be the most "efficient" and comprehensive in terms of protecting property rights, including the position of secured creditors, but they may not necessarily be any better or worse than the codes in some modern European civilian jurisdictions. In short, De Soto's thesis - and others which suggest that the development of the West is explicable on the basis of a better formal structure of property rights that Western economies possess and developing countries lack - seems much too pat, as well as being belied by the facts.

\section{IMPROVING CREDIT COST AND AVAILABILITY}

Studies by various international financial institutions have suggested a correlation between enhanced security rights, on the one hand, and greater access to, and cheaper, credit on the other. ${ }^{63}$ This correlation has been borne out in an empirical study by Haselmann and Pistor examining the effect of legal change in respect of collateral rights on the lending behaviour of banks in 12 transition economies. ${ }^{64}$ The study concludes that banks increase the supply of credit subsequent to legal change and that the ability to "collateralise" or use assets as security seems to be an important determinant of credit supplied in the economy. It also finds that foreign-owned banks respond more strongly to legal change than incumbents. This is consistent with the proposition that, especially in emerging and transition economies, information asymmetries are of greater concern compared to developed

57 See the review of The Mystery of Capital by C Woodruff in (2001) 39 Journal of Economic Literature 1215.

58 See U Mattei, “The Peruvian Civil Code: property and plunder” (2005) 6 Global Jurist Topics, fnn. 18, 19, and see also U Mattei and L Nader, Plunder: When the rule of law is illegal (Oxford: Wiley-Blackwell 2008).

59 De Soto, The Mystery of Capital, n. 47 above, p. 60.

60 Ibid. p. 53.

61 See B Kozolchyk, "A road map to economic development through law: third parties and comparative legal culture" (2005) 23 Arizona Journal of International and Comparative Law 1, pp. 2-3: "a merchant's inventory is nowhere represented by a 'property document' ... The preceding objections are not intended as quibbles; they go to the heart of de Soto's argument."

62 See Mattei, "Peruvian Civil Code", n. 58 above: "Latin American private law derives in large measure from Spanish and Portuguese law."

63 World Bank Group, Secured Transactions Systems, n. 6 above, pp. 7-13.

64 See R Haselmann and K Pistor, "How the law affects lending" (2009) 23 Review of Financial Studies 549. 
markets. Collateral rights tend to reduce information gaps between lenders and borrowers; to even the playing field between foreign and domestic lenders; and to open up the credit market to new participants.

Where asset collateralisation is legally possible, it is argued that all but the largest borrowers should get better terms on a secured rather than an unsecured loan. Better terms can take the form of lower interest rates, larger loans relative to income and also more generous repayment periods. A more prosaic example has been cited in the case of a credit union for International Monetary Fund (IMF) and World Bank employees: ${ }^{65}$

When the borrowers offer collateral for a loan instead of only a signature, the credit union offers better terms: it will lend at interest rates that are about half as high, make loans that are five to ten times larger relative to income and give the borrower as much as five times longer to repay.

In other cases, however, there may not be a simple trade-off between interest rates and the cost of credit. For instance, sub-prime borrowers may be charged high interest rates and also required to provide security. With blue-chip borrowers, on the other hand, capacity to service the loan is not considered to be an issue. Security does not enter into the reckoning and the competition among lenders for a valuable source of business keeps interest rates low. Moreover, there are greater costs incurred in secured as distinct from unsecured lending. ${ }^{66}$ Secured loans are more expensive to set up since the expenses involved in arranging and documenting the transaction are higher. For this reason, it is not just loans to blue-chip borrowers but sometimes small loans, or loans to buyers with strong repayment records, that may be offered on an unsecured basis. While evidence suggests that 60-65 per cent of loans to businesses in the United States are secured, the precise effect of security on credit cost and availability is very difficult, if not impossible, to verify empirically. ${ }^{67}$

\section{Critical perspectives on the harmonisation and modernisation of secured credit law}

This section addresses three critical perspectives on UNCITRAL's harmonisation and modernisation agenda. The first considers general issues of fairness, in particular, fairness to unsecured creditors from enhanced recognition of security rights. The second perspective looks at secured credit law reform as part of a neoliberal economic agenda pushed by international organisations that also includes privatisation and marketisation of key sectors of a national economy. The third perspective considers secured credit reform as a possible instrument of American foreign policy and American economic interests.

\section{SECURITY AND FAIRNESS}

The concept of security runs counter to instinctive conceptions of fairness in that it may involve one creditor being paid whereas other creditors remain unpaid. ${ }^{68}$ In short, the idea of proportionate satisfaction of creditor claims, i.e. pari passu distribution, is disturbed. This concern can be met in various ways. For instance, one might argue that the general instrumentalist justifications for security override individual conceptions of fairness. In other words, increased credit creation and lower-cost credit will help to stimulate economic activity and lead to better economic conditions for all. Moreover, to the extent that security is seen as a fair exchange for the credit, the secured creditor has bargained for security and

65 See Fleisig, "The economics of collateral", n. 14 above, pp. 81, 85.

66 See, generally, R Mann, "Explaining the pattern of secured credit” (1997) 110 Harvard Law Review 626.

67 See Lopez de Silanes, "Turning the key to credit", n. 28 above, p. 10.

68 For a strong critique of pari passu, see, generally, R Mokal, "Priority as pathology: the pari passu myth" (2001) 60 CLJ 581. 
priority, whereas other creditors have not. Consequently, it does not seem unfair to privilege the secured creditor over other creditors who could equally have contracted for security but chose not to do so. On the other hand, there may be involuntary creditors, i.e. creditors not in a contractual relationship with the debtor, who are not in a position to bargain for security. Also there are other non-adjusting creditors, or poorly adjusting creditors, where it is unrealistic to suppose that they could bargain for security or where the transaction costs of doing so are too great. These creditors in a weak bargaining position are perhaps most likely to be the ones that will be hit hardest by the debtor's insolvency. The insolvency may impact disproportionately on them in that they are not very capable of sharing or passing on the costs of the loss. Large financial institutions most likely to take security are in a much better position to pass on losses.

Employees and small trade creditors are typically non-adjusting, or poorly adjusting, creditors. Different jurisdictions may have different ways of protecting such creditors whether through social safety nets, or insurance schemes, or the like. Other possible approaches would be to impose restrictions on the taking of security thereby leaving a margin of unsecured assets that are available for payment of unsecured debts, or else to set aside a proportion of secured realisations for the benefit of unsecured creditors. The UNCITRAL Guide, however, follows the thread of Article 9 of the American Uniform Commercial Code and counsels against this, recognising the "full" priority of security rights.

\section{SECURED CREDIT AND NEOLIBERAL ECONOMIC REFORMS}

Secured credit law reform is generally promoted on the basis that it will foster market-based decision-making on credit issues. Reform is often seen as part of an overall economic agenda - the so-called Washington consensus - that includes privatisation and marketisation. ${ }^{69}$ They may be viewed as interlinked ingredients in an overall growth and development strategy.

In the early 1990s, international financial institutions pushed the advantage of a rapid privatisation process but, in many instances, this led to a massive transfer of state resources into the hands of privileged insiders, or the economically powerful. There is a growing recognition that rapid privatisation is not the best prescription for reform. ${ }^{70}$ The Chinese experience indicates that a slower, more gradual process is more conducive to long-term economic stability. ${ }^{71}$ A gradual process of privatisation allows the restructuring of large firms to take place before their move, in whole or in part, into the private sector.

One of the presumptions underpinning the Washington consensus is that markets will intrinsically lead to efficient outcomes, but the recent global financial crisis has, instead, highlighted the possibility of desirable government intervention that can guide economic growth and make everyone better off. Commentators, such as Joseph Stiglitz, have also criticised the focus of the Washington consensus on GDP, which is seen as the be-all-andend-all of development. He argues that:

because GDP is relatively easy to measure, it has become a fixation of economists. The trouble with this is that we measure what we strive for.

69 See J Stiglitz, Globalisation and its Discontents (London: Penguin 2002), pp. 16, 53-4.

70 Ibid. p. 6: "countries were told by the West that the new economic system would bring them unprecedented prosperity. Instead, it brought unprecedented poverty . . . The contrast between Russia's transition, as engineered by the international economic institutions, and that of China, designed by itself, could not be greater."

71 See J Ohnesorge, "Developing development theory: law and development orthodoxies and the North East Asian experience" (2007) 28 University of Pennsylvania Journal of International Economic Law 219 and see also J Ohnesorge, "The rule of law, economic development, and the developmental states of Northeast Asia" in C Antons (ed.), Law and Development in East and South East Asia (London: Routledge/Curzon 2003). 
Sometimes, increases in GDP are associated with poverty reduction, as was the case in East Asia. But that was not an accident: governments designed policies to make sure that the poor shared in the benefits. Elsewhere, growth has often been accompanied by increased poverty and sometimes even lower income levels for individuals in the middle. ${ }^{72}$

It is submitted that this is a valuable insight and that the merits of secured credit reform should be disaggregated from wider notions about the alleged efficacy of market-based decision-making, and the implementation of a privatisation agenda.

\section{THE UNCITRAL GUIDE AS AN INSTRUMENT OF AMERICAN ECONOMIC POWER}

There have been many analyses of the role of transplants in the legal modernisation and harmonisation process. ${ }^{73}$ It is the case that a variety of factors drive countries to adopt legal transplants from other jurisdictions and models of greater, or lesser, sophistication have been used to explain the typology of transplants. ${ }^{74}$ Professor Alan Watson, for example, has acknowledged that reception and transplants come in all shapes and sizes, speaking of an imposed reception, solicited imposition, penetration, infiltration, crypto-reception, inoculation, and so on. ${ }^{75}$ Another approach is to propound a straightforward distinction between coercive transplants and voluntary receptions. The notion of "coercive" transplants can be used to explain the relationship between a colonial power and its dependencies whereby the law of the mother country is imposed on its "foreign" possessions and territories as part of the project of imperial governance. The concept of "voluntary" reception explains situations where the aura, or prestige, of a particular jurisdiction persuades other countries to adopt its laws. ${ }^{76}$

The sufficiency of this basic taxonomy has been challenged. In particular, the distinction between coercive and voluntary transplants could be seen as a matter only of degree, and not of kind. There is not a straightforward dichotomy between "free" or "coercive" transplants of a foreign model - law is a detailed and complex machinery of social control that cannot effectively function without some cooperation from local officials, usually consisting of a professional elite, possibly created by the imperial power. This elite provides the degree of consent to the reception of foreign legal ideas that is necessary for any transplant to occur. ${ }^{77}$ In this connection, one might also make use of the notion of reflexive law, thereby acknowledging that the influence exerted by exporting or

72 See J Stiglitz, Making Globalization Work (London: Penguin 2006), p. 45. These points are also highlighted by Stiglitz in his foreword to Polanyi, The Great Transformation, n. 11 above.

73 See, generally, W Twining, "Social science and diffusion of law" (2005) 32 Journal of Law and Society 203, p. 205; "Diffusion of law: a global perspective" (2004) 49 Journal of Legal Pluralism 1. See also F Schauer, The Politics and Incentives of Legal Transplantation, Centre for International Development at Harvard Working Paper No 44 (2000), available at www.hks.harvard.edu/var/ezp_site/storage/fckeditor/file/pdfs/centers-programs/ centers/cid/publications/faculty/wp/044.pdf (last accessed 1 September 2011); T Waelde and J Gunderson, "Legislative reform in transition economies: Western transplants - a shortcut to social market economy status" (1994) 43 ICLQ 347.

74 But for a somewhat different perspective, see O Kahn-Freund, "On uses and misuses of comparative law" (1974) 37 MLR 1 and, for a response, see A Watson, "Legal transplants and law reform" (1976) 92 LQR 79. See also W Ewald, "Comparative jurisprudence (11): the logic of legal transplants" (1995) 43 AJCL 489.

75 A Watson, Legal Transplants: An approach to comparative law (Edinburgh: Scottish Academic Press 1974), p. 30.

76 See U Mattei, "A theory of imperial law: a study on US hegemony and the Latin resistance" (2002) 10 Indiana Journal of Global Legal Studies 383, p. 385.

77 See Berkowitz et al., "Transplant effect", n. 22 above, who suggest that indigenous law-making operates as a kind of focal point for cooperative law-making behaviour which then serves as the focal point for cooperative economic behaviour. See also G Teubner, "Legal irritants: good faith in British law or how unifying law ends up in new divergences" (1998) 61 MLR 11. 
"hegemonic" jurisdictions is most likely to be effective when it seeks to achieve its ends not by direct prescription but by inducing second order effects on the part of social actors in the receiving state. ${ }^{78}$ One may also tie in the concept of path dependency. ${ }^{79}$ The law, and lawyers, tend to absorb change by digging deeper into existing soil, rather than branching out into new fields. Political and other influences may trigger legal development and cause the law to produce certain outcomes but the form that represents these outcomes is determined by the legal doctrine prevailing in the jurisdiction concerned. ${ }^{80}$ In short, the law develops in a path-dependent fashion.

Another commentator, Professor Ugo Mattei, has sought to explain transplants on the basis of prestige or efficiency. ${ }^{81}$ While acknowledging that each single legal transplant has its own peculiarities that make it different from every other, Mattei deploys economic analysis to explain the perceived convergence of modern legal systems as a movement towards efficiency, despite the large variety of institutional backgrounds. A synergy is also said to exist between "efficiency" and "prestige" with the most efficient models being seen as the more prestigious. The "efficiency" notion links up with concepts of regulatory competition. This implies convergence around a single, efficient system which wins out through the competitive process. But the evidence about regulatory competition suggests that it may produce rules that are far from optimal from the viewpoint of economic theory. ${ }^{82}$ There is also the risk of "social dumping" 83 and a so-called race to the bottom. 84 Proponents of the "efficiency" thesis then have to fall back on arguments about the longterm benefits of market solutions. In some cases, the idea of co-evolution may better explain the process whereby countries observe and emulate practices in jurisdictions to which they are closely related by trade and institutional connections. The co-evolution concept assumes that a variety of diverse systems may exist side by side with each one retaining its viability. More fundamentally, a recent empirical study of private credit in over 100 countries over 25 years has amassed evidence contradicting the hypothesis that legal institutions converge toward the more successful ones over time. ${ }^{85}$ In addition, the study suggests that since credit institutions vary so much across countries and legal origins, the evidence is also inconsistent with the "functional convergence" hypothesis holding that

78 See, generally, G Teubner, "Substantive and reflexive elements in modern law" (1983) 17 Law and Society Review 239.

79 L Bebchuk and M Roe, "A theory of path dependence in corporate ownership and governance" (1999) 52 Stanford Law Review 127.

80 See, generally, E Micheler, Property in Securities: A comparative study (Cambridge: CUP 2007), ch. 15, "Legal development as a path-dependent process" and see the statement at p. 228, "Legal doctrine causes the law to develop path-dependently". See also H Spamann, "Contemporary legal transplants: legal families and the diffusion of (corporate) law" (2009) Brigham Young University Law Review 1813; J Armour, S Deakin, P Lele and M Siems, "How do legal rules evolve? Evidence from a cross-country comparison of shareholder, creditor, and worker protection" (2009) 57 AJCL 579.

81 U Mattei, "Efficiency in legal transplants: an essay in comparative law and economics" (1994) 14 International Review of Law and Economics 3. See also A Ogus, "Competition between national legal systems: a contribution of economic analysis to comparative law" (1999) 48 ICLQ 405 and see, generally, F von Hayek, "Competition as a discovery procedure" (2002) 5 Quarterly Journal of Austrian Economics 3, p. 9.

82 See D Esty and D Geradin (eds.), Regulatory Competition and Economic Integration: Comparative perspectives (Oxford: OUP 2001).

83 In the context of EC employment law, the European Court of Justice made specific reference to social dumping in Laval un Partneri Ptd v Svenska (341/05) [2007] ECR I-5751, para. 103.

84 See, generally, C Barnard, "Social dumping and race to the bottom: some lessons for the EU from Delaware?" (2000) 25 European Law Review 57; L Enriques and M Gelter, "Regulatory competition in European company law and creditor protection" (2006) 7 European Business Organization Law Review 417.

85 See S Djankov, C McLiesh and A Shleifer, "Private credit in 129 countries" (2007) 84 Journal of Financial Economics 299. 
institutions in different countries, while distinct on the surface, functionally converge to accomplish the same goals.

Evidence of a lack of a convergence, however, is not necessarily inconsistent with the proposition that certain legal systems may hold an appeal on prestige or other grounds. John Braithwaite and Peter Drahos in their seminal book on Global Business Regulation ${ }^{86}$ have spoken of how models are adopted

when they appeal to identities that we hold dear. An identity that is particularly crucial in this regard is that of being successful, modern, civilised, advanced. The periphery models the centre in the world system because of this pursuit of modernity in identity (or postmodernity, for the truly avant-garde).

The French economist Michel Albert has spoken of the irresistible force of US legal expansionism. ${ }^{87}$ US legal paradigms gain a competitive advantage from the political and ideological sway exercised by the United States. Alternative approaches are overwhelmed by American political and cultural influences. Albert explains the spread of American influences using notions of seductiveness and appeal. In his view, the intrinsic characteristics of the neo-American model exalt the success of risk-taking, gambling and "glittery" behaviour.

In the same vein, another commentator has talked about how the European Community method of rational planning, bureaucratic solutions, suppression of political passion and a steady incrementalism is incapable of igniting the popular emotions in a way that would allow Europe to mount a true global challenge to the US. ${ }^{88}$

Mattei has now moved away from his earlier reliance on "prestige" or "efficiency" to propound a theory of "imperial law": 89

Imperial law is produced, in the interest of international capital, by a variety of both public and private institutions, all sharing a gap in legitimacy . . . Imperial law is shaped by a spectacular process of exaggeration, aimed at building consent for the purpose of hegemonic domination. Imperial law subordinates local legal arrangements world-wide ... Predatory economic globalization is the vehicle, the all-mighty ally, and the beneficiary of imperial law.

In the realm of literary and cultural discourse, notions of imperialism and American hegemony have been advanced by Edward Said. ${ }^{90} \mathrm{He}$ talks about American culture's phenomenally incorporative capacity and a system of pressures and constraints which induces other states to follow the essentially imperial identity and direction of US norms. ${ }^{91}$ In his view, the pressures are subtle, and generally indirect. ${ }^{92}$ Said makes the point that: ${ }^{93}$

American attitudes to American greatness, to hierarchies of race, to the perils of other revolutions ... have remained constant, have dictated, have obscured the

86 J Braithwaite and P Drahos, Global Business Regulation (Cambridge: CUP 2000), p. 591.

87 M Albert, Capitalism against Capitalism: How America's obsession with individual achievement and short-term profit has led it to the brink of economic collapse (London: Whurr 1993).

88 See S Dillon, “Looking for the progressive empire: where is the European Union's foreign policy?” (2004) 19 Connecticut Journal of International Law 275, p. 278.

89 See U Mattei, "A theory of imperial law", n. 76 above. See also J Gardner, Legal Imperialism, American Lawyers and Foreign Aid in Latin America (Madison: University of Wisconsin Press 1980).

90 E Said, Culture and Imperialism (London: Chatto \& Windus 1993). See also M Hardt and A Negri, Empire (Cambridge, MA: Harvard UP 2000).

91 Said, Culture and Imperialism, n. 90 above, p. 392.

92 Ibid. p. 401.

93 Ibid. p. 7. 
realities of empire, while apologists for overseas American interests have insisted on American innocence, doing good, fighting for freedom.

Said also links his theory of imperialism with a law-making creed that suggests it is the goal of US foreign policy to bring about a world increasingly subject to the rule of law, as defined in US terms.

In the sphere of secured credit, the UNCITRAL Guide can be considered as an instrument by which the norms set out in Article 9 of the American Commercial Code are writ large across the globe. The Guide reproduces the key features of Article 9, emphasising the removal of restrictions on the taking of security, all-assets security, notice filing of security interests along American lines, and the full priority of security rights.

US private and public interests combined and collaborated in the formulation and development of the Guide. It is hardly surprising that agencies of the US government, as well as US private interests, should act to defend what they consider to be US business interests. Leading economies, including the US, "have a collective interest in promoting generalized dependency and reverence from the periphery". ${ }^{4}$ But, as one US commentator remarks:

efforts to export US legal models are more likely to succeed if they eschew detailed, distinctively US-derived prescriptions in favour of presenting advise or exemplars in terms of more "general" standards, "international" norms, “universal” principles ...95

The work of bodies such as UNCITRAL is considered to represent best international practice. ${ }^{96}$ The US, by virtue of its economic power, and the associated prestige of its economic and legal models, heavily influences the work of such bodies and, putting the point simply, what is considered to be good for the US is also considered to be good for the world. ${ }^{97}$ But there are many who disagree with the assessment of what is good not only for the world but also for the US.

\section{Conclusion}

Security rights give the credit-provider property rights, normally in the debtor's assets. The whole harmonisation and modernisation agenda appears to be driven largely by a desire to remove restrictions on the taking of security. This is because of a widespread belief that a "liberal" secured transactions regime promotes economic growth. In many World Bank and other studies, the availability of credit has been identified as one of the key factors driving economic growth. Lack of access to credit, and in particular low-cost credit, is seen as a major constraint on economic development. While economic and other factors may hamper access to credit, legal, regulatory and institutional frameworks are also seen significantly to contribute to this problem. In many jurisdictions, the laws relating to secured transactions are fragmented and antiquated. Businesses may be unable to utilise the full value of their

94 See the following statement by the Commercial Finance Association (CFA), General Counsel: (UN Press Release ECO/56 L/3061, 29 March 2010): “CFA members, which include large United States banks but also smaller lenders, often make loans to companies located in other countries supported by collateral. The guide will help countries to modernize their laws, so that lenders who are interested in making loans in other countries will know with certainty and predictability what their rights and obligations are."

95 See J de Lisle, "Lex Americana? United States legal assistance, American legal models and legal change in the post-communist world and beyond" (1999) 20 University of Pennsylvania Journal of International Economic Law 179, p. 269, and see also his comment at p. 202 about the US government promoting the indirect export of US models through multilateral organisations that shape international standards.

96 See, generally, K Pistor, "The standardization of law and its effect on developing economies" (2002) 50 AJCL 97.

97 See Braithwaite and Drahos, Global Business Regulation, n. 86 above, p. 587. 
assets or, if they try to do so, they are straightjacketed down a particular and restrictive path. Unlocking the value of collateral to serve as security is seen as a highly important task.

But the harmonisation and modernisation agenda also has its critics. The law of secured finance is often perceived to embody cultural attitudes and public policy choices that vary greatly among states. In this area of commercial law, sovereignty issues remain central since many of the rules governing enforcement of security rights reflect policy interests that are external to the credit relationship itself. An agreement between debtor and creditor cannot regulate completely the operation of the resulting security right against third parties. In the event of debtor insolvency, there is an additional layer of policy issues to be considered. The rules governing the distribution of the debtor's assets may reflect local social goals. Polanyi has graphically pointed out the dangers in terms of detrimental social consequences if theoretically free markets are left to enjoy full reign.

Changes to law and legal doctrine in a particular jurisdiction often mirror, to a greater or lesser extent, changes that have taken place in other jurisdictions. The desire for change may stem from societal developments or from a desire to promote the social and economic infrastructure of a particular country. Turkey exemplifies a country that set out on a path of modernity as a result of top-down political leadership and then consciously borrowed laws and legal institutions from other jurisdictions that were considered to offer a superior product. ${ }^{98}$ Changes may also to a greater extent be coerced. In decades and centuries past, the UK exported the common law to its overseas territories and possessions and, generally, these former colonies persisted with the common law as they gained political independence. The French Napoleonic Code found its way to Spain as a result of military conquest and from there it passed to the Hispanic world of Central and South America. In recent times, coercion has come in more subtle forms, perhaps through conditions attached to international loans to developing countries from the World Bank and IMF.

The US strongly influences if not entirely controls the workings of these international financial institutions, in particular the IMF. World Bank and IMF conditionality may require economic austerity measures, and also changes to the economic structures of the country concerned, including privatisation and restructuring of state-owned enterprises and strengthening the role of the private sector. The conditions may also require changes to corporate law, as well as the enactment of measures to enhance the availability of credit by means of a modern secured transactions regime. Prescriptions in this regard are most unlikely to be expressed as crudely as "Enact Article 9 of the American Uniform Commercial Code". Instead, they are more likely to call for progress and advancement in line with best international practice. ${ }^{99}$ Best international practice is considered to be represented by the work of organisations such as UNCITRAL. The US, through economic power and the associated prestige of its economic and legal models, heavily influences the work of UNCITRAL and analogous bodies. Certainly, the UNCITRAL Secured Transactions Guide reproduces the key features of Article 9 of the American Uniform Commercial Code in apparent preference to alternative models from other jurisdictions.

98 See E Orucu, "Turkey: change under pressure" in E Orucu, S. Attwool and S Coyle, Studies in Legal Systems: Mixed and mixing (London: Kluwer 1996), p. 89. See also E Orucu, Critical Comparative Law: Considering paradoxes for legal systems in transition (Deventer: Kluwer 1999), p. 81: "No single legal system served as the model. The choice was driven in some cases by the perceived prestige of the model, in some by efficiency and in others by chance. Choosing a number of different models may have given the borrowings 'cultural legitimacy' as the desire to modernise and westernise was not beholden to any one dominant culture."

99 See Pistor, "Standardisation of law", n. 96 above, p. 108, on how the influence of a foreign law can be obscured by the use of an international instrument. 
While some of the rhetoric about the economic efficacy of property rights, including security rights, is certainly overblown, there is nevertheless some empirical evidence that enhanced and more widely available security rights may open the door to greater economic growth. On the other hand, there is little evidence that following a detailed blueprint such as the American Article 9 writ large in the UNCITRAL Secured Transactions Guide will necessarily give a further boost to growth prospects. Indeed, it may even harm them. A study based on the Eastern-European experience demonstrates various potential inefficiencies when law is transplanted into an "alien" implementing or enforcing environment. ${ }^{100}$ The study sees indigenous norms and institutions functioning better than transplanted ones and, while the possibility of borrowing from other countries is not precluded, the "fit" of foreign with domestic law is enhanced by meaningful adaptation of imported laws to local conditions. ${ }^{101}$ There are no magical elixirs that bring about a happy ending to the quest for growth. ${ }^{102}$ In short, there is no Holy Grail and the UNCITRAL Secured Transactions Guide, if and to the extent that it implies otherwise, is a false god.

100 See Berkowitz et al., "Transplant effect”, n. 22 above.

101 Referring to Cass Sunstein - "the meaning of legal statements is a function of social norms, not of the speaker's intentions" in "On the expressive function of law" (1996) 144 University of Pennsylvania Law Review 2021, p. 2050, and see also C Sunstein, "Social norms and social roles" (1996) 96 Columbia Law Review 903, p. 925.

102 See W Easterly, The Elusive Quest for Growth: Economists' adventures and misadventures in the Tropics (Cambridge, MA: MIT Press 2001), p. 289. 